\title{
Neonatal hypokalemia
}

This article was published in the following Dove Press journal:

Research and Reports in Neonatology

28 March 2012

Number of times this article has been viewed

\section{Dilek Sarici'}

S Umit Sarici ${ }^{2}$

'Kecioren Research and Education Hospital, Kecioren, Ankara, ${ }^{2}$ Chief of Division of Neonatology, Division of Neonatology, Department of Pediatrics, Gulhane Military Medical Academy, Ankara, Turkey
Correspondence: S Umit Sarici Division of Neonatology, Department of Pediatrics, Gulhane Military Medical Academy, Etlik-06018, Ankara, Turkey Tel +90532 255584 I

Fax +90 312 36I 7074

Email umit@umitsarici.com
Abstract: In this article, distribution of potassium $\left(\mathrm{K}^{+}\right)$in body fluids, pathophysiology, causes, clinical signs and symptoms, and the evaluation and treatment of neonatal hypokalemia are reviewed. $\mathrm{K}^{+}$is the most important intracellular cation and normal serum $\mathrm{K}^{+}$is stabilized between 3.5 and $5.5 \mathrm{mEq} / \mathrm{L}$. Hypokalemia may be caused by increased renal losses, increased extrarenal (gastrointestinal) losses, redistribution or prolonged insufficient $\mathrm{K}^{+}$intake. Clinical signs and symptoms occur as the result of functional changes in striated muscle, smooth muscle, and the heart. Hypokalemia is usually asymptomatic when $\mathrm{K}^{+}$levels are between 3.0 and $3.5 \mathrm{mEq} / \mathrm{L}$; however, there may sometimes be slight muscle weakness. Moderate hypokalemia is observed when serum $\mathrm{K}^{+}$is between 2.5 and $3.0 \mathrm{mEq} / \mathrm{L}$. Proximal muscle weakness is observed most commonly in lower extremities; cranial muscles are normal, but constipation and distention are prominent. Severe hypokalemia develops when serum $\mathrm{K}^{+}$falls below $2.5 \mathrm{mEq} / \mathrm{L}$. Rhabdomyolysis, myoglobinuria, severe muscle weakness, paralysis, respiratory distress, and respiratory arrest are observed. The clinical signs and symptoms may be unremarkable in cases of chronically developing hypokalemia; however, appropriate treatment is essential when serum $\mathrm{K}^{+}$level falls below $2.5 \mathrm{mEq} / \mathrm{L}$ as the most dangerous complication of hypokalemia is fatal cardiac arrythmia, and changes visible with electrocardiography may not always correlate with the level of hypokalemia. Sodium $\left(\mathrm{Na}^{+}\right), \mathrm{K}^{+}$, chloride $\left(\mathrm{Cl}^{-}\right)$, bicarbonate, creatinine, blood sugar, magnesium $(\mathrm{Mg})$, plasma renin activity, aldosterone, and blood gases should be investigated by laboratory testing. Aspartate aminotransferase, alanine aminotransferase, creatinine kinase, and creatinine kinase isoenzyme MB should be studied if rhabdomyolysis is suspected. In urine sample density, $\mathrm{pH}, \mathrm{Na}^{+}, \mathrm{K}^{+}, \mathrm{Cl}^{-}, \mathrm{Mg}$, creatinine, and myoglobinuria (blood reaction is positive in the absence of erythrocytes on microscopic examination of urine) should be investigated. The primary aim of therapy is to prevent and treat life-threatening cardiac and muscular complications. However, in the presence of severe symptomatic hypokalemia and gastrointestinal problems such as ileus, the intravenous route may be used in cases where serum $\mathrm{K}^{+}$level is usually below $2.6 \mathrm{mEq} / \mathrm{L}$. $\mathrm{K}^{+}$given in intravenous fluids should not exceed $40 \mathrm{mEq} / \mathrm{L}$. In case of emergency, $0.3-1 \mathrm{mEq} / \mathrm{kg}$ of $\mathrm{K}^{+}$may be given intravenously over 1 hour. When higher concentrations $(60-80 \mathrm{mEq} / \mathrm{L})$ are needed, infusion through a central vein under electrocardiography monitoring may be used.

Keywords: neonatal, hypokalemia, newborn

\section{Introduction}

Potassium $\left(\mathrm{K}^{+}\right)$is the most important intracellular cation. The distribution of $\mathrm{K}^{+}$inside and outside of the cell is $98 \%$ and $2 \%$, respectively. Normal serum $\mathrm{K}^{+}$is stabilized between 3.5 and $5.5 \mathrm{mEq} / \mathrm{L}$. Changes in $\mathrm{pH}$ values of blood and other body components may lead to changes in serum $\mathrm{K}^{+}$levels via changes in intracellular and extracellular 
$\mathrm{K}^{+}$concentrations. An increase of $0.1 \mathrm{U}$ in blood $\mathrm{pH}$ (towards alkalosis) causes a decrease of $0.3-1.3 \mathrm{mEq} / \mathrm{L}$ in serum $\mathrm{K}^{+}$ concentration, with the entry of $\mathrm{K}^{+}$into the cell. ${ }^{1}$

$\mathrm{K}^{+}$equilibrium and distribution provided by the $\mathrm{Na}^{+}-\mathrm{K}^{+}-$ ATP'ase pump between the intracellular and extracellular regions is the major determinant of membrane potential at rest. This is significant for the stabilization and excitability of cell membranes, especially those of neuromuscular tissues. ${ }^{2}$ The most dangerous complication of hypokalemia is fatal cardiac arrhythmias.

Total body $\mathrm{K}^{+}$is provided by the equilibrium occurring between $\mathrm{K}^{+}$intake, and loss via urine and the gastrointestinal tract. ${ }^{3}$ Almost all of $\mathrm{K}^{+}$ingested through diet is absorbed. The kidneys secrete more than $90 \%$ of daily intake, and are the organs primarily responsible for the elimination of $\mathrm{K}^{+}$. The kidneys are only capable of secreting half of very high-dose $\mathrm{K}^{+}$(over 4-6 hours), with the rest transiently distributed into the cell. This intracellular distribution, which has only a very limited capacity, nevertheless has a very important role in the equilibrium of acute changes in serum $\mathrm{K}^{+}$. Even the transfer of small amounts $(1 \%-2 \%)$ of intracellular $\mathrm{K}^{+}$ into the extracellular region can easily increase serum $\mathrm{K}^{+}$to dangerous levels. Many factors affect the distribution of $\mathrm{K}^{+}$ between the intracellular and extracellular regions, and these factors are summarized in Table 1.

Under normal conditions, $\mathrm{K}^{+}$excretion via the gastrointestinal route is negligible; however, colonic excretion increases in the presence of chronic renal failure, dominating the role of the kidneys. Any disorder in renal $\mathrm{K}^{+}$equilibrium may lead to excessive loss or accumulation.

\section{Causes of neonatal hypokalemia}

Neonatal hypokalemia may be caused by increased renal losses, increased extrarenal (gastrointestinal) losses, redistribution, or prolonged insufficient $\mathrm{K}^{+}$intake. Laboratory data for blood pressure, acid-base status, electrolytes, blood-urine osmolality, and renin-aldosterone axis should be collected before starting treatment in any patient with hypokalemia. Causes of neonatal hypokalemia are listed in Table 2. ${ }^{2-9}$

Table I Factors affecting the distribution of $\mathrm{K}^{+}$between the intracellular and extracellular regions

\begin{tabular}{ll}
\hline Insulin & $\begin{array}{l}\text { Increase of it causes hypokalemia, and decrease } \\
\text { of it causes hyperkalemia } \\
\beta \text {-agonists cause hypokalemia, and } \beta \text {-antagonists } \\
\text { Catecholamines }\end{array}$ \\
Acid-base status & $\begin{array}{l}\text { Metabolic alkalosis causes hypokalemia and } \\
\text { metabolic acidosis causes hyperkalemia }\end{array}$ \\
Tissue injury & Causes hyperkalemia \\
\hline
\end{tabular}

Table 2 Causes of neonatal hypokalemia

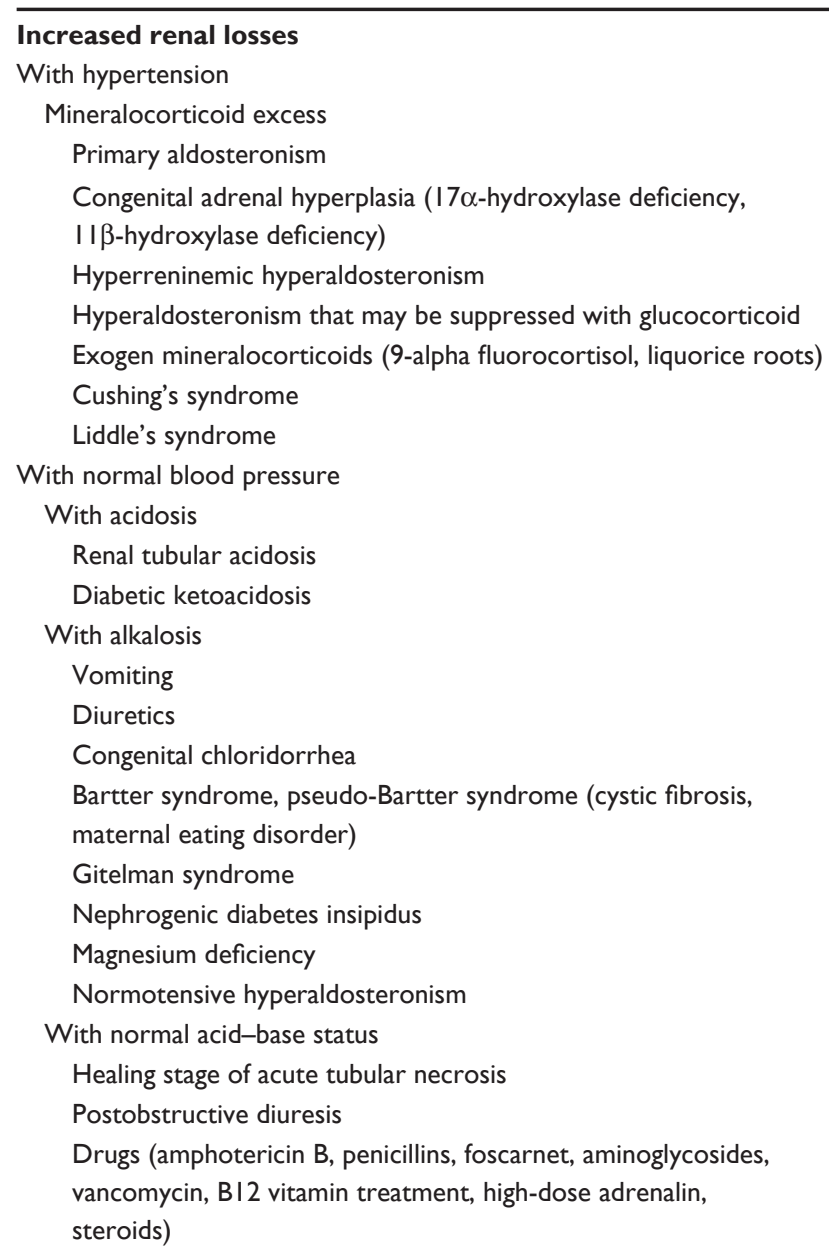

\section{Extrarenal losses}

Diarrhea

Gastrointestinal fistulas, ileostomy

Villous adenoma

Malabsorption

Excessive laxative use

Excessive diaphoresis

Use of dialysate with low $\mathrm{K}^{+}$

\section{Redistribution}

Alkalosis

Insulin

Calcium channel blockers

Theophylline, caffeine

Lithium

$\beta$-agonists

Barbiturate coma

Thyrotoxicosis

Hypothermia

Acute brain injury

Barium intoxication

Frozen-packed red blood cell transfusion

Familial hypokalemic periodic paralysis

Prolonged insufficient $\mathrm{K}^{+}$intake

Prolonged starvation

Insufficient $\mathrm{K}^{+}$support in total parenteral nutrition 


\section{Clinical signs and symptoms of neonatal hypokalemia}

Clinical signs and symptoms occur as the result of functional changes in striated muscle, smooth muscle, and the heart. ${ }^{10,11}$ Hypokalemia is usually asymptomatic when $\mathrm{K}^{+}$levels are between 3.0-3.5 mEq/L; however, there may sometimes be a slight muscle weakness. ${ }^{11}$ Moderate hypokalemia is observed when serum $\mathrm{K}^{+}$is between $2.5-3.0 \mathrm{mEq} / \mathrm{L}$. Proximal muscle weakness is observed most commonly in lower extremities; cranial muscles are normal, but constipation and distention are prominent. Severe hypokalemia develops when serum $\mathrm{K}^{+}$falls below $2.5 \mathrm{mEq} / \mathrm{L}$. Rhabdomyolysis, myoglobinuria, severe muscle weakness, paralysis, respiratory distress, and respiratory arrest are observed. Fasciculation and tetany are observed in muscles. Electrocardiography (ECG) changes such as an increase in the amplitude of P-waves, prolongation in PR and QT intervals, decrease in the amplitude of T-waves, inversion in T-waves, depression in ST segments, and the appearance of U-waves are observed as cardiac findings (Figure 1). ${ }^{11}$ However, ECG changes may not always correlate with the level of hypokalemia. Left ventricular hypertrophy and heart failure may be detected, and the risks of digoxin toxicity, dysrhythmia, and sudden death increase. It also weakens the effect of insulin. Paralytic ileus and gastric dilatation develop when the smooth muscles are affected.

The clinical signs and symptoms may be unremarkable in cases of chronically developing hypokalemia; however, appropriate treatment is essential when serum $\mathrm{K}^{+}$levels fall below $2.5 \mathrm{mEq} / \mathrm{L}$, as the most dangerous complication of hypokalemia is fatal cardiac arrhythmias, and ECG changes may not always correlate with the level of hypokalemia. It should also be noted that severe hypokalemia inversely affects growth and development, and its effects on the $\mathrm{Na}^{+}-\mathrm{K}^{+}-\mathrm{ATP}^{\prime}$ ase pump and all kinds of muscles must be considered.

Rhabdomyolysis may affect renal function, as renal concentration capacity decreases with prolonged hypokalemia and causes polyuria. Prolonged hypokalemia increases urinary chloride $\left(\mathrm{Cl}^{-}\right)$loss, decreases bicarbonate and citrate excretion, and increases ammonia synthesis. Consequently, persistent metabolic alkalosis develops with hypokalemia. ${ }^{11}$

\section{Evaluation of neonatal hypokalemia}

Vomiting, diarrhea, ileostomy, nasogastric drainage, and drugs (ie, use of diuretics in babies with bronchopulmonary dysplasia causes hypokalemia with alkalosis) should be questioned in the anamnesis. $\mathrm{Na}^{+}, \mathrm{K}^{+}, \mathrm{Cl}^{-}$, bicarbonate, creatinine, blood sugar, magnesium $(\mathrm{Mg})$, plasma renin activity, aldosterone, and blood gases should be investigated by laboratory testing. Aspartate aminotransferase, alanine aminotransferase, creatinine kinase, and creatinine kinase isoenzyme MB should be studied if rhabdomyolysis is suspected. In urine sample density, $\mathrm{pH}, \mathrm{Na}^{+}, \mathrm{K}^{+}, \mathrm{Cl}^{-}, \mathrm{Mg}$, creatinine, and myoglobinuria (blood reaction is positive in the absence of erythrocytes on microscopic examination of urine) should be investigated. Gastric dilatation and ileus should be investigated by upright abdominal X-ray. An ECG should be ordered for cardiac findings and echocardiography may be necessary.

Measurement of blood pressure, blood gas analysis, and measurement of urinary $\mathrm{Na}^{+}, \mathrm{K}^{+}, \mathrm{Cl}^{-}, \mathrm{Mg}$ and creatinine

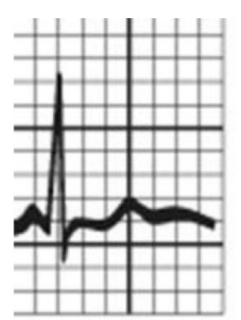

$2.8 \mathrm{mEq} / \mathrm{L}$

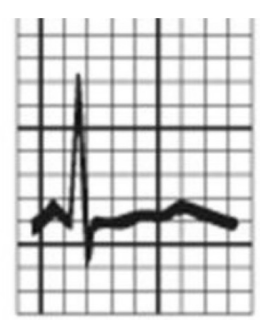

$2.5 \mathrm{mEq} / \mathrm{L}$

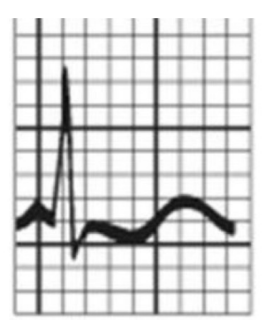

$2.0 \mathrm{mEq} / \mathrm{L}$

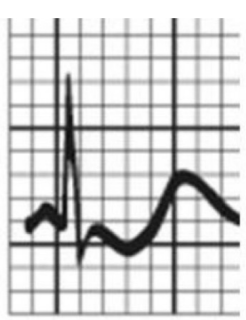

$1.7 \mathrm{mEq} / \mathrm{L}$

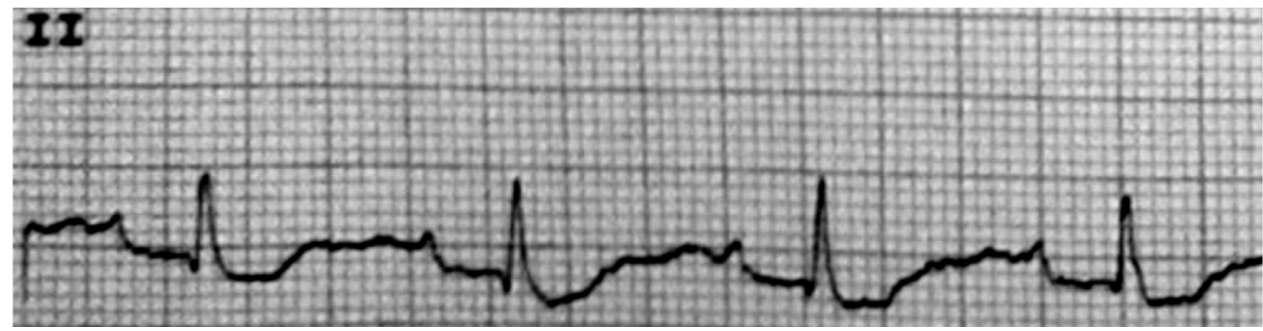

Figure I Electrocardiography changes in hypokalemia. 
are the most important steps in the etiologic evaluation of hypokalemia (Figure 2). ${ }^{12,13}$ In the evaluation of patients, the first step is to determine whether the ratio of urinary $\mathrm{K}^{+}$ to creatinine (mmol:mmol) is below or above $1.5 .{ }^{14} \mathrm{If} \mathrm{Mg}$ is high in urine, renal $\mathrm{Mg}$ loss should be considered. If urinary $\mathrm{Cl}^{-}$level is below $10 \mathrm{mEq} / \mathrm{L}$, gastrointestinal losses (vomiting, pyloric stenosis, drainage, fistulas, ileostomy, diarrhea, and chloridorrhea) should be considered. ${ }^{11,13}$ In babies with a urinary $\mathrm{Cl}^{-}$level above $20 \mathrm{mEq} / \mathrm{L}$, diuretic use and Bartter and Gitelman syndromes should be considered.

In cases of increased blood pressure aldosteronism, Cushing's syndrome, and congenital adrenal hyperplasia (17 alpha hydroxylase and 11 beta hydroxylase deficiencies) should be considered. If urinary $\left(\mathrm{Na}^{+}+\mathrm{K}^{+}\right)-\mathrm{Cl}^{-}$is $\geq-10$, gastrointestinal $\mathrm{K}^{+}$loss with normal gap metabolic acidosis should be considered. If urinary $\left(\mathrm{Na}^{+}+\mathrm{K}^{+}\right)-\mathrm{Cl}^{-}$is $\leq-10$, renal $\mathrm{K}^{+}$loss, renal tubular acidosis, drugs, and ureteral diversion should be considered. Vomiting, nasogastric drainage and prolonged diuretic use should be considered if urinary $\mathrm{Cl}^{-}$is below $20 \mathrm{mEq} / \mathrm{L}$, with hypokalemia and metabolic alkalosis. Diuretic use and mineralocorticoid increase should be considered if urinary $\mathrm{Cl}^{-}$is above $20 \mathrm{mEq} / \mathrm{L}$ with hypokalemia and metabolic alkalosis. ${ }^{11}$

\section{Treatment of neonatal hypokalemia}

The primary aim of therapy is to prevent and treat life-threatening cardiac and muscular complications. The secondary aim is to replenish the body's $\mathrm{K}^{+}$stores. There is no absolute way of determining real $\mathrm{K}^{+}$deficit,

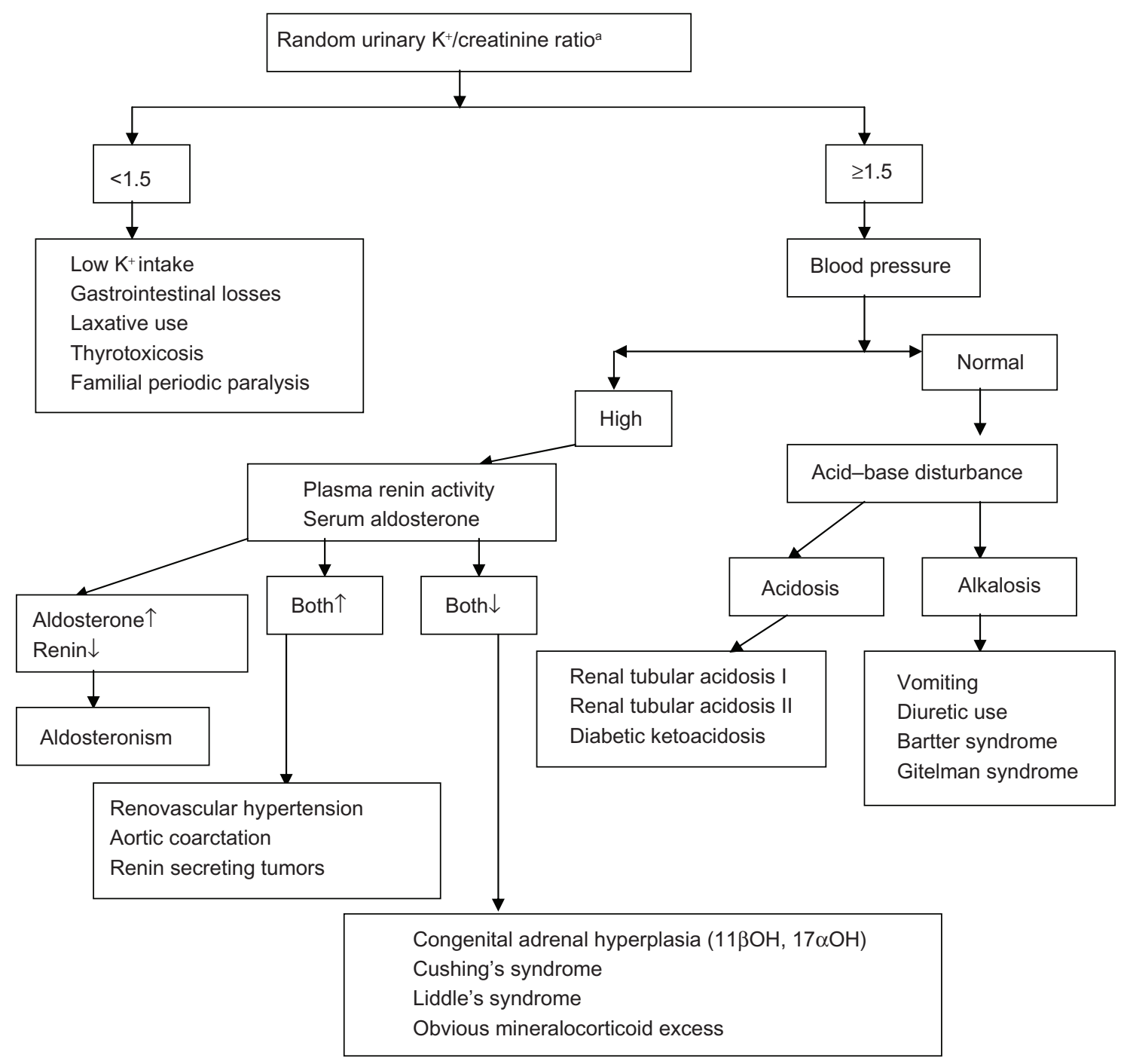

Figure 2 Algorithma used in the evaluation of neonatal hypokalemia. Note: ${ }^{\mathrm{a}} \mathrm{mmol} / \mathrm{L} \mathrm{K} / \mathrm{mmol} / \mathrm{L}$ creatinine. 
as there is no correlation between plasma $\mathrm{K}^{+}$concentration and the body's $\mathrm{K}^{+}$stores. A decrease of $1 \mathrm{mEq} / \mathrm{L}$ in serum $\mathrm{K}^{+}$concentration with $\mathrm{K}^{+}$loss usually refers to a $10 \%-30 \%$ decrease in body $\mathrm{K}^{+}$. In such conditions as acidosis and hyperosmolarity, plasma $\mathrm{K}^{+}$concentration may reflect a lower value than actual $\mathrm{K}^{+}$stores, and rapid correction of acidosis with bicarbonate may lower serum $\mathrm{K}^{+}$concentration rapidly.

The safest treatment of $\mathrm{K}^{+}$is via the oral/enteral route. The normal daily required intake of $\mathrm{K}^{+}$is $1-2 \mathrm{mEq} / \mathrm{kg} /$ day. However, in the presence of severe symptomatic hypokalemia and gastrointestinal problems such as ileus, the intravenous route may be used in cases where serum $\mathrm{K}^{+}$level is usually below $2.6 \mathrm{mEq} / \mathrm{L}$. $\mathrm{K}^{+}$given in intravenous fluids should not exceed $40 \mathrm{mEq} / \mathrm{L}$. In case of emergency, $0.3-1 \mathrm{mEq} / \mathrm{kg}$ of $\mathrm{K}^{+}$may be given intravenously over 1 hour. ${ }^{15}$ When higher concentrations (60-80 mEq/L) are needed, infusion through a central vein under ECG monitoring may be used. Dextrose should not be used in initial fluids because increases in insulin secretion secondary to dextrose infusion may lower plasma $\mathrm{K}^{+}$concentrations even further.

The choice of the type of $\mathrm{K}^{+}$salt depends on the clinical situation. $\mathrm{KCl}$ is usually appropriate if hypovolemia is present. In the presence of simultaneous metabolic acidosis, other $\mathrm{K}^{+}$ salts producing $\mathrm{K}^{+}$bicarbonate, $\mathrm{K}^{+}$citrate, and $\mathrm{K}^{+}$acetate may be given. In the presence of a phosphate-depleting situation such as diabetic ketoacidosis, $\mathrm{K}^{+}$phosphate may be used. It should be kept in mind that correction of total body $\mathrm{K}^{+}$deficit may take days and even weeks. In cases of hypokalemia resistant to treatment, hypomagnesemia should be considered. In these cases, $\mathrm{K}^{+}$levels normalize following magnesium treatment.

\section{Disclosure}

This article was published as a chapter in Turkish in the Textbook of Pediatric Endocrinology edited by Selim
Kurtoglu and published by Nobel Tip in Istanbul, Turkey in 2011. The authors report no conflicts of interest in this work.

\section{References}

1. Simmons CF. Fluid and electrolyte management. In: Cloherty JP, Stark AR, editors. Manual of Neonatal Care. Philadelphia, PA: Lippincott Williams and Wilkins; 1998:87-100.

2. Chadha V, Alon US. Asid-baz ve elektrolit dengesizlikleri [Disturbances of acid-base status and electrolyte imbalances]. In: Narli N, Balat A Bolum, editors. Pediatrik Tani ve Tedavide Pratik Yaklasimlar [Practical approaches in pediatric diagnosis and treatment]. Istanbul, Turkey: Nobel Tip Kitabevleri; 2007:447-464. Turkish.

3. Ors R. Yenidoganda hiperpotasemi ve hipopotasemi [Hyperpotasemia and hypopotasemia in the newborn]. Turkiye Klinikleri J Pediatr Sci. 2008;4(2):113-118. Turkish.

4. Weiss-Guillet EM, Takala J, Jakob SM. Diagnosis and management of electrolyte emergencies. Best Pract Res Clin Endocrinol Metab. 2003;17(4):623-651.

5. Nanji AA. Drug-induced electrolyte disorders. Drug Intell Clin Pharm. 1983;17(3):175-185.

6. Fang W, Chen JY, Fang Y, Huang JL. Epinephrine overdose-associated hypokalemia and rhabdomyolysis in a newborn. Pharmacotherapy. 2005;25(9):1266-1270.

7. Rastergar A, Soleimani M. Hypokalemia and hyperkalemia. Postgrad Med J. 2001;77(914):759-764.

8. Le J, Adler-Shohet FC, Nguyen C, Lieberman JM. Nephrotoxicity associated with amphotericin B deoxycholate in neonates. Pediatr Infect Dis J. 2009;28(12):1061-1063.

9. Alfonzo AV, Isles C, Geddes C, Deighan C. Potassium disordersclinical spectrum and emergency management. Resuscitation. 2006;70(1):10-25.

10. Mandal AK. Hypokalemia and hyperkalemia. Med Clin North Am. 1997;81(3):611-639.

11. Schaffer TJ, Wolford RW. Disorders of potassium. Emerg Med Clin North Am. 2005;23(3):723-747.

12. Assadi F. Diagnosis of hypokalemia: a problem-solving approach to clinical cases. Iran J Kidney Dis. 2008;2(3):115-122.

13. Lim S. Approach to hypokalemia. Acta Med Indones. 2007;39(1): 56-64.

14. Groeneveld JH, Sijpkens YW, Lin SH, Davids MR, Halperin ML. An approach to the patient with severe hypokalaemia: the potassium quiz. OJM. 2005;98(4):305-316.

15. Galloway E, Doughty L. Electrolyte emergencies and acute renal failure in pediatric critical care. Clin Ped Emerg Med. 2007;8(3):176-189.
Research and Reports in Neonatology

\section{Publish your work in this journal}

Research and Reports in Neonatology is an international, peer-reviewed, open access journal publishing original research, reports, editorials, reviews and commentaries on neonatal health. The manuscript management system is completely online and includes a very quick and fair

\section{Dovepress}

peer-review system. Visit http://www.dovepress.com/testimonials.php to read real quotes from published authors. 